RASĀYAN J. Chem.

Vol. 14 | No. 2 |794-798| April - June | 2021 ISSN: 0974-1496 | e-ISSN: 0976-0083 | CODEN: RJCABP http://www.rasayanjournal.com http://www.rasayanjournal.co.in

\title{
REDUCING NITRATE AND TOTAL PHOSPHATE BY USING OXIDATION DITCH WITH MICROALGAE Chlorella sp. REACTOR
}

\author{
Euis Nurul Hidayah ${ }^{\bowtie}$, Okik Hendriyanto Cahyonugroho, Aulia Ulfah \\ Farahdiba and Rizka Novembrianto \\ Department of Environmental Engineering, University of Pembangunan Nasional "Veteran", \\ Jawa Timur, 60294, Indonesia \\ Corresponding Author: euisnh.tl@upnjatim.ac.id
}

\begin{abstract}
Microalgae is a microscopic plant that has chlorophyll for carrying out photosynthesis. Chlorella sp. is one of the most easily found microalgae in the aquatic. Chlorella $s p$ needs some nutrients such as nitrate and total phosphate for growing. There are many ways to develop microalgae, and an algae reactor is more effective on a large scale. Algae reactor has the same concept with oxidation ditch by using different microorganisms. This study applied an oxidation ditch reactor filled with microalgae Chlorella $s p$ for treating domestic wastewater in terms of nitrate and phosphate concentration. Variation of rotational speed airbrush (45 and $60 \mathrm{rpm})$ and ratio volume of waste to microalgae (3:1, $4: 1,5: 1,6: 1)$ were performed. The sample was collected for 5 days and measured for nitrate and phosphate concentration. The result shows that the optimum removal of nitrate and total phosphate is about $63.64 \%$ and $66.15 \%$, respectively, with an under-speed variation of $60 \mathrm{rpm}$ and a volume ratio of 3: 1 . This study concludes that oxidation ditch reactor-filled microalgae Chlorella $s p$ had performed an effective process in removing nitrate and total phosphate under optimum speed rotation and a low ratio of waste microalgae.
\end{abstract}

Keywords: Microalgae, Algae Reactors, Nitrates, Total P, Chlorella sp.

RASĀYAN J. Chem., Vol. 14, No.2, 2021

\section{INTRODUCTION}

Eutrophication in river bodies has been caused by a high concentration of nitrate and phosphate in the aquatic system. ${ }^{1}$ This situation has occurred because of the disposal of waste into water bodies without proper treatment. Therefore, it is needed to create potential wastewater treatment at a low cost and considering it environmentally friendly. Utilizing microalgae is one of the treatment options regarding the biological processes. ${ }^{2}$ Microalgae is microscopic celled plant single, capable of producing their food by absorbing $\mathrm{CO}_{2}{ }^{3}$. Also, microalgae can grow in regions with temperatures above $15^{\circ} \mathrm{C}$. Therefore, microalgae have a high potential for significant production and to be developed in Indonesia. ${ }^{4}$ Several microalgae are often used, such as Dunaliella salina, Euglena gracilis, Synechococcus sp, Spirulina. Their usage depends on the percentage of waste volume and amount of microalgae obtained at optimal conditions, under the waste volume of $20 \%$ and light intensity of $4000 \operatorname{lux}^{6}$. Other studies also state that microalgae Chlorella $s p$. is better than species Scenedesmus $s p$. for degrading nitrate and total phosphate, which reached about $98.2 \%$ and $70 \%{ }^{5}$. Previous studies have revealed that high turbulence of flow in oxidation ditch through stirring, airbrushing, mixing, etc., will increase algal growth, preventing deposition of biomass. $^{7}$ Also, a volume comparison between waste and microalgae is carried out to determine maxima microalgae added in the wastewater. ${ }^{8}$ Between microalgae, the results decrease optimal those that reduce high levels of pollutants and are easily found in nature, i.e., Chlorella $s p .{ }^{9}$ Chlorella $s p$. require nutrients for growth in nitrates and total phosphate in wastewater based on the influent volume of waste and algae used. ${ }^{10}$ One technology used for developing microalgae is a high-level algae pond, which has higher productivity than conventional wastewater treatment ponds. ${ }^{11}$ Oxidation ditch algae reactor has a similar concept with oxidation ditch processing. However, in this system, microalgae are performed to remove pollutants. The oxidation ditch algae reactor's optimum process was influenced by many factors, such as

Rasayan J. Chem., 14(2), 794-798(2021)

http://dx.doi.org/10.31788/ RJC.2021.1426157

This work is licensed under a CC BY 4.0 license. 
RASĀYAN J. Chem.

light absorption, volume ratio, channel depth, and aerator rotation speed. ${ }^{12}$ In previous studies, varying rotation speed, immersion depth, and slope angle obtained the best results at conditions of a rotation speed of $48 \mathrm{rpm}$ with a depth of $5.5 \mathrm{~cm}$ and the best slope angle of $47^{0} .{ }^{13}$ According to the description above, this study aims to apply an oxidation ditch reactor filled with microalgae Chlorella $\mathrm{sp}$. for treating domestic wastewater in term of nitrate and phosphate concentration with a variation in the ratio of the volume of waste and microalgae and the rotational speed of the brush aerator conducted in batch scale.

\section{EXPERIMENTAL}

This research was conducted to see the effectiveness of the oxidation ditch algae reactor in reducing nitrate and phosphate concentration using microalgae Chlorella $s p$. The main parameters to be analyzed are nitrate, total phosphate, and chlorophyll content, supporting parameters such as $\mathrm{pH}$, temperature, and DO. The study was conducted on a batch scale, with a variable volume ratio and brush rotation speed. The oxidation ditch algae reactor was filled with $300 \mathrm{~L}$ of raw wastewater, and the process has been carried out for 5 days. Previously, microalgae have been acclimatized with a wastewater concentration of $30 \%$ for 6 days. Comparison of waste and microalgae volumes are without microalgae as control, $3: 1,4: 1,5: 1$, and 6:1. In comparison, the brush aerator's rotational speed used in algae reactors is $45 \mathrm{rpm}$ and $60 \mathrm{rpm}$. The rotational speed of the brush aerator will cause stirring in the reactor. Stirring the reactor will make it easier for nutrients to mix up evenly. ${ }^{14}$ Stirring can also minimize the formation deposition at the base of the reactor during microalgae photosynthesis. ${ }^{15}$ The reactor used has a shape like a running field called an algae reactor.

\section{RESULTS AND DISCUSSION}

\section{Effect of Rotational Speed and Volume Comparison for Total Phosphate Removal}

Total phosphate is one of the essential elements for all organisms to transform energy, forming cells, store and replicate genetic information. Microalgae also include organisms that need energy for cell growth, not only from total growth but also from sunlight. ${ }^{16}$ Total phosphate is included as an element or limiting factor for growth in microalgae both at sea and in lakes. ${ }^{17}$ Microalgae obtain energy from sunlight and use organic materials such as total P for cell growth. ${ }^{16}$ After 5 days of experimental was carried out under various variations, it was found that the percentage of total phosphate removal increased during process treatment. However, it tends to increase stably from day one to day five. On the last day of observation, the highest percentage decrease in total $\mathrm{P}$ was obtained from each variable.

The results showed that the total phosphate concentration is relatively the same in each volume ratio used. The observation on the first day obtained the highest total phosphate removal in the control variation of $10.77 \%$ with an initial total phosphate of $0.565 \mathrm{mg} / \mathrm{L}$ to $0.504 \mathrm{mg} / \mathrm{L}$. The second-day observation obtained the highest total phosphate removal in the control variation of $22.42 \%$, with an initial total phosphate of $0.565 \mathrm{mg} / \mathrm{L}$ to $0.438 \mathrm{mg} / \mathrm{L}$. The third-day observation showed that the highest total phosphate removal was in the 5: 1 variation of $35.4 \%$, with the initial total phosphate $0.673 \mathrm{mg} / \mathrm{L}$ to $0.435 \mathrm{mg} / \mathrm{L}$. Observations on the fourth day showed the highest total phosphate removal in the $3: 1$ variation of $44.7 \%$ with an initial total $\mathrm{p}$ of $0.808 \mathrm{mg} / \mathrm{L}$ to $0.447 \mathrm{mg} / \mathrm{L}$. Observing the fifth day, the highest total phosphate removal was a $3: 1$ variation of $57.4 \%$ with an initial total phosphate of $0.808 \mathrm{mg} / \mathrm{L}$ to $0.344 \mathrm{mg} / \mathrm{L}$, as shown in Fig.-1 and Fig.-2.

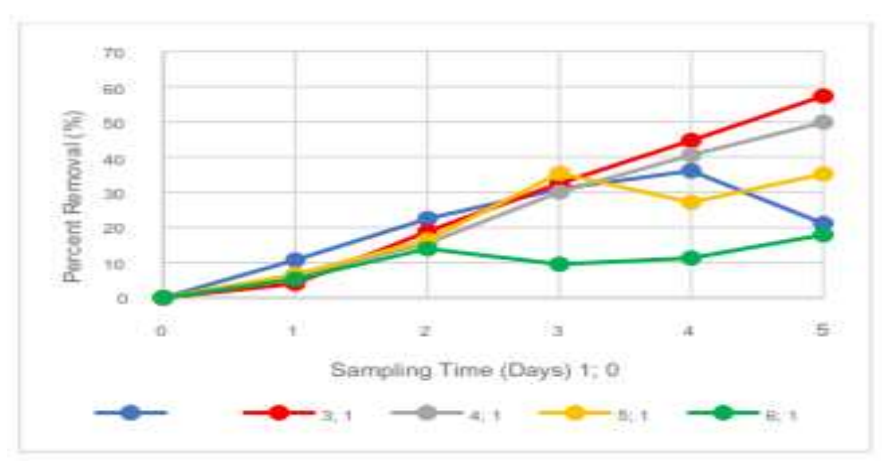

Fig.-1: Percentage Removal of Total Phosphate Under Various Volume of Microalgae with Rotation Speed $45 \mathrm{rpm}$ 
RASĀYAN J. Chem.

Vol. 14 | No. 2 |794-798| April - June | 2021

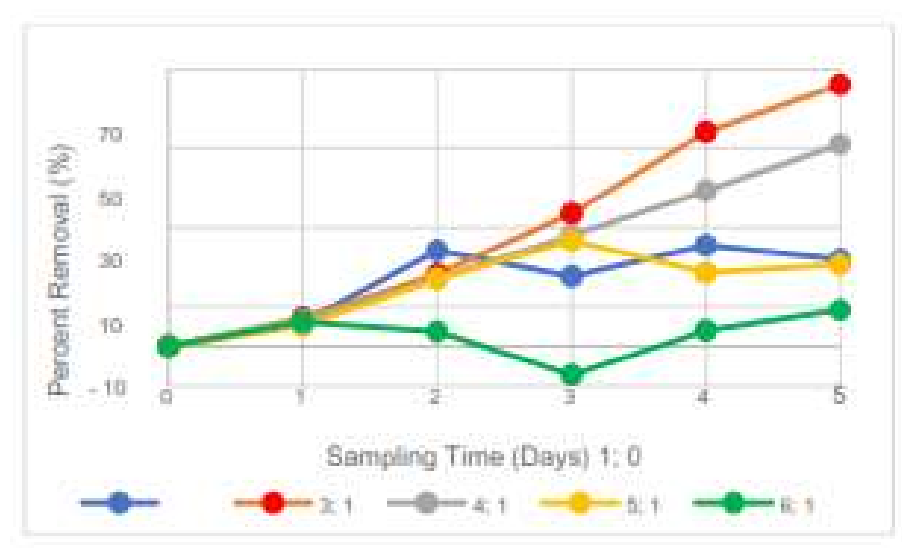

Fig.-2: Percentage Removal of Total Phosphate Under Various Volume of Microalgae with Rotation Speed $60 \mathrm{rpm}$

The results showed that in addition to an increase in percent removal in total phosphate, there is also a decrease in percent removal in some variations, such as variations 4:1 and 3:1. It indicated that microalgae pass through the adaptation phase well as proven with decreasing total phosphate from day 0 to day 5 . The high amount of microalgae will significantly reduce the total number of phosphate because the needed total phosphate is getting higher for microalgae growth. ${ }^{12}$ The optimum reduction of total phosphate is $66.15 \%$, which occurs in volume ratio $3: 1$ at the rotation speed of $60 \mathrm{rpm}$ on the last day of observation. Removal of total phosphate is probably due to microalgae that can secrete mucus to seal calcite and form crystals on the cell surface. ${ }^{18}$ Calcite is a type of natural mineral that has a high total adsorption capacity of phosphate. Calcite captured by microalgae will be attached to the surface of microalgae cells EPS (extracellular polymeric substance). EPS will have an essential role in absorbing total phosphate in microalgae. ${ }^{19}$ Other microorganisms, such as bacteria, will naturally grow in this algae reactor because the concept is oxidation ditch, and raw wastewater may contain microorganisms. In algae reactors, there are aerobic conditions, accumulating organisms polyphosphate, such as polyphosphate accumulating organisms (PAO) returns polyphosphate deposits through phosphate extraction from wastewater. ${ }^{2}$ Type of bacteria Acinetobacter, classified as PAO, can reduce phosphate and live in aerobic conditions. ${ }^{20}$

\section{Effect of Variation Rotation Speed and Volume to Nitrate Reduction.}

A nitrate is a form of nitrogen compound that is a stable compound and is an essential element for protein synthesis for plants and animals. ${ }^{10}$ The nitrification process can help in decomposing organic matter in the waste. It also can reduce the amount of nitrate in domestic wastewater. Nitrification is giving oxygen to ammonia to be converted into nitrates and nitrites by microorganisms. Also, microalgae are low-level microorganisms that have eukaryotic properties and have chlorophyll. ${ }^{21}$ Microalgae can reduce nitrate compounds in domestic wastewater. ${ }^{22}$ Nitrates found in domestic wastewater will be a source of microalgae nitrogen for its growth. Preliminary observations show that nitrate concentrations are relatively the same in each volume ratio used. After the experiment was carried out within 5 days with various variations, the results obtained percent reduction in nitrate varies in each variable. However, it tends to increase from day one to day five. On the last day of observation, the highest percentage of nitrate reduction was obtained from each variable.

Results preliminary observations show that nitrate concentrations are relatively the same in each volume ratio used. The observations on the first day found that the highest nitrate absorption was at a 3:1 variation of $13.2 \%$ with an initial nitrate of $4.244 \mathrm{mg} / \mathrm{L}$ to $3.682 \mathrm{mg} / \mathrm{L}$. The second-day observation found the highest nitrate absorption at a $3: 1$ variation of $27.828 \%$ with an initial nitrate of $4.244 \mathrm{mg} / \mathrm{L}$ to $3.063 \mathrm{mg} / \mathrm{L}$. The third-day observation found that the highest nitrate absorption was at $5: 1$ variation of $35.3 \%$ with initial nitrate $4,275 \mathrm{mg} / \mathrm{L}$ to $2,765 \mathrm{mg} / \mathrm{L}$. The fourth-day observation found the highest nitrate absorption at a $3: 1$ variation of $40.1 \%$ with an initial nitrate of $4.244 \mathrm{mg} / \mathrm{L}$ to $2.543 \mathrm{mg} / \mathrm{L}$. The fifth-day observation showed the highest absorption of nitrate in a 3:1 variation of $50.1 \%$ with an initial nitrate of $4.244 \mathrm{mg} / \mathrm{L}$ to 2.081 $\mathrm{mg} / \mathrm{L}$, as shown in Fig.-3 and Fig.-4 
RASĀYAN J. Chem.

Vol. 14 | No. 2 |794-798| April - June | 2021

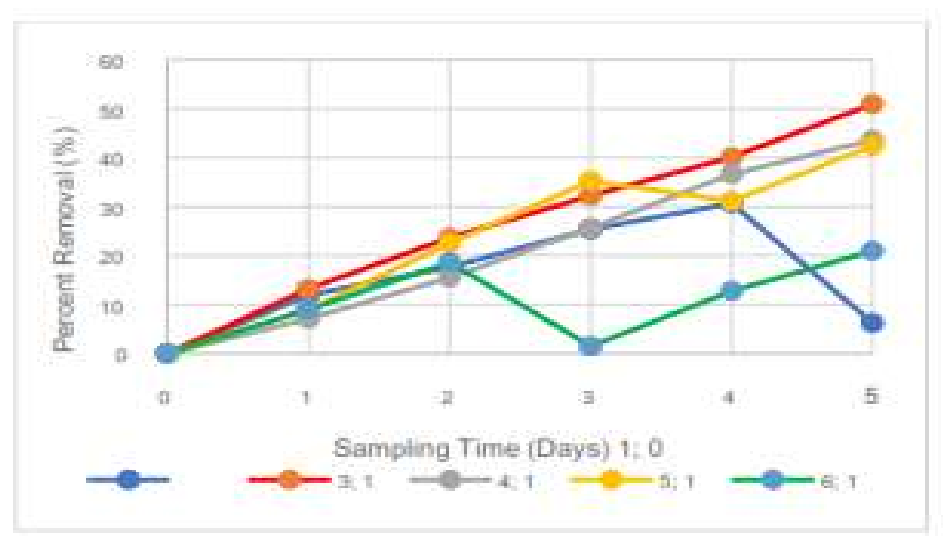

Fig.-3: Percentage Removal of Nitrate Under Various Volume of Microalgae with Rotation Speed 45 rpm

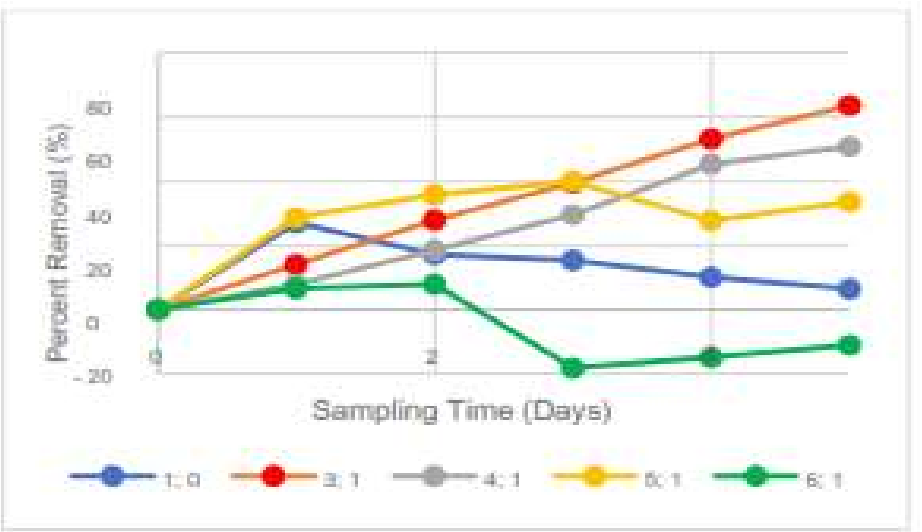

Fig.-4: Percentage Removal of Nitrate Under Various Volume of Microalgae with Rotation Speed $60 \mathrm{rpm}$

Initial observations show that nitrate concentrations are relatively the same in each volume ratio used. The observations on the first day obtained the highest nitrate removal at a $5: 1$ variation of $28.7 \%$ with an initial nitrate of $4.275 \mathrm{mg} / \mathrm{L}$ to $3.048 \mathrm{mg} / \mathrm{L}$. The second-day observation obtained the highest nitrate removal at a $5: 1$ variation of $35.7 \%$ with an initial nitrate of $4.275 \mathrm{mg} / \mathrm{L}$ to $2.747 \mathrm{mg} / \mathrm{L}$. The third-day observation found that the highest nitrate absorption was at $5: 1$ variation of $39.9 \%$ with initial nitrate $4.275 \mathrm{mg} / \mathrm{L}$ to 2.569 $\mathrm{mg} / \mathrm{L}$. Observations on the fourth day showed the highest nitrate removal at $3: 1$ variation of $53.2 \%$ with an initial nitrate of $4.244 \mathrm{mg} / \mathrm{L}$ to $1.986 \mathrm{mg} / \mathrm{L}$. Observations on day five were obtained the highest nitrate removal at variations of $63.6 \%$ with an initial nitrate of $4.244 \mathrm{mg} / \mathrm{L}$ to $1.543 \mathrm{mg} / \mathrm{L}$. Microalgae can reduce pollutant compounds in domestic wastewater. ${ }^{22}$ Figure 4 showed a relatively stable decrease in nitrate under variation of 4:1 and 3:1 during 5 days observation. As for the control and comparison of 6:1 and 5:1, there was an increase in nitrate concentration on certain days but increased the following day again. The instability of nitrate reduction in the control can occur because of the activity of bacteria and microorganisms adjusting to the new environmental conditions. High levels of nitrate in the 5:1 and 6:1 variation can be caused by cells of Chlorella $s p$ was in a developing condition, and it needs a small number of nutrients for growth. If the amount of nitrate excess, fertilization will occur, and it causes microalgae growth rapidly while the dissolved oxygen available in the reactor bath is fixed. When the microalgae respire, it caused competition to get oxygen. This is the main issue that some microalgae cannot do respiration because of the limited amount of oxygen, in it caused microalgae dead. ${ }^{23}$

\section{CONCLUSION}

From the results of the research and discussion that has been described above, it can be concluded that algae reactors reduce nitrate levels and the total $\mathrm{p}$ of $63.64 \%$ and $66.15 \%$ within 5 days. The comparison volume with microalgae is $3: 1$, and it directly affects nitrate removal and the optimum total phosphate. The brush 
aerator's rotation speed does not directly affect the reduction of nitrate and total phosphate, and the optimum rotation speed is $60 \mathrm{rpm}$.

\section{ACKNOWLEDGEMENT}

The financial support provided to this research by Direktorat Jenderal Pendidikan Tinggi Indonesia through Penelitian Dasar Scheme for multi-year, with Contract No. 12/UN63.8/LT - Kontrak/III/2020 is greatly appreciated.

\section{REFERENCES}

1. R. Singh, R. Birru, and G. Sibi, Journal of Environmental Protection, 8(1), 1(2017), DOI: $10.4236 /$ jep.2017.81001

2. P.P. Kumar, Y.P. Kumar, and B.V. Rao, Rasayan Journal of Chemistry, 10(3), 1025(2017), DOI: 10.7324/RJC.2017.1031683

3. A.M.N. Caruana, and Z. Amzil, Microalgae and toxins. In: I.A. Levine, J. Fleurence (eds) Microalgae in health and disease prevention, Elsevier, (2018)

4. E.T. Salem, A. Ashoor, M.A. Fatma, andY.S. Noori, Rasayan Journal of Chemistry, 6(1), 1(2013).

5. A.A. Ansari, A.H. Khoja, A. Nawar, and M. Qayyum, Applied Water Science, 7(7), 4151(2017), DOI: $10.1007 / \mathrm{s} 13201-017-05749$

6. A.U. Farahdiba, E.N. Hidayah, G.A. Asmar, and Y.W. Myint, Nature Environment and Pollution Technology, 19(2), 809(2020), DOI:10.46488/NEPT.2020.v19i02.038

7. L. Delgadillo-mirquez, F. Lopes, B. Taidi, and D. Pareau, Biotechnology Reports, 11, 18(2016), DOI: $10.1016 /$ j.btre.2016.04.003

8. O.H. Cahyonugroho, D.D. Yuniawati, and E.N. Hidayah, Rasayan Journal of Chemistry, 12(4), 2306(2019), DOI: 10.31788/RJC.2019.1245439

9. T. Cai, S.Y. Park, and Y. Li, Y., Renewable and Sustainable Energy Reviews, 19, 360(2013), DOI: 10.1016/j.rser.2012.11.030

10. M. Leloup, R. Nicolau, V. Pallier, C. Y'epr'emian, and G.F. Cathalifaud, Journal of Environmental Sciences, 25, 1089(2013), DOI:10.1016/S10010742(12)602083

11. D. Sutherland, Water Research Journal, 70, 86(2015), DOI:10.1016/ j.watres.2014.11.0 50

12. R. Munoz, and B. Guieysse, Water Research, 40, 2799(2006), DOI:10.1016/j.watres.2006.06.011

13. M.S. Madeira, C. Cardoso, P.A. Lopes, D. Coelho, C. Afonso, N.M. Bandarra, and J.A.M. Prates, Livestock Science, 205, 111(2017), DOI:10.1016/j.livsci.2017.09.020

14. Y. Hendrawan, and S. Anggraini, Journal of Engineering of Tropical Agriculture and Biosystems, 5(1), 9(2017).

15. C. Sumithra, and S. Karthikeyan, Rasayan Journal of Chemistry, 7(2), 149(2014).

16. M.L. Wells, P. Potin, J.S. Craigie, J.A. Raven, S.S. Merchant, K.E. Helliwell, A.G. Smith, M.E. Camire, and S.H. Brawley, Journal of Applied Phycology, 29, 949(2017), DOI:10.1007/s108110160974-5

17. W. Komarawidjaja, Journal of Environmental Engineering, 12(3), 241(2011).

18. A. Regista, M. Litaay, and M.R. Umar, Makassar Biology Journal, 2(1), 1(2017).

19. H. Lu, Y. Feng, Y. Wu, L. Yang, and H. Shao, Science of the Total Environment, 568(50), 838(2016), DOI: $10.1016 /$ j. scitotenv.2016.06.010

20. M. Wagner, A. Loy, R. Nogueira, U. Purkhold, N. Lee, and H. Daems, International Journal of General and Molecular Microbiology, 81(1-4), 665(2002), DOI:10.1023/A: 1020586312170

21. S. Imelda, C. Claudia, O. Lambi, and S. Swastika, Natural Science: Journal of Science and Technology, 7(2), 148(2018)

22. L. Xin, H. Ying, G. Ke, and X.S. Ying, Bioresource Technology, 101(14), 5494(2010), DOI:10.1016/j.biortech.2010.02.016

23. A. Tunggul, S. Haji, and M. Khotimah, Functional Design of Green Roof Algae for Cultivation Industrial Waste Water, 6(1),79(2018).

[RJC-6157/2020] 